\title{
Use of probiotics for sustainable shrimp culture in Southeast Asia
}

VALERIANO L. CORRE, JR. ${ }^{1}$ AND ROSY L. JANEO ${ }^{2}$

${ }^{1}$ Institute of Aquaculture, College of Fisheries and Ocean Sciences, University of the Philippines in the Visayas, Miagao, Iloilo 5023 Philippines and ${ }^{2}$ Brackishwater Aquaculture Center, Institute of Aquaculture, College of Fisheries and Ocean Sciences, University of the Philippines in the Visayas, Leganes, Iloilo 5003 Philippines

summary: The use of probiotics in bioremediation or biological control is now accepted in the field of aquaculture. Bioremediation is the practice of using supplemental bacteria for treating wastewater. In order to achieve and maintain good water quality within the system and improve the quality of discharge water.

In Thailand, Japan, Malaysia, Indonesia and other Asian countries, bioremediation is used in shrimp and other high value fish farms to improve water quality and to control the growth of pathogenic bacteria. A study on the use of probiotics as biocontrol in shrimp ponds was conducted in the Philippines. Results showed increased shrimp survival and production due to reduced growth of pathogenic microorganisms, particularly the luminous bacteria. Only minimal water exchange was required due to improved water quality inside the ponds.

\section{KEYWORDS: probiotics, shrimp culture, bioremediation, sustainable}

\section{INTRODUCTION}

Shrimp farming is one of the major dollar-earning industries in Southeast Asia. During the early $70 \mathrm{~s}$, shrimps were considered as a secondary crop in finfish farms. The high demand in the international market paved the way for the development of various culture techniques. In the early $80 \mathrm{~s}$, shrimp farming became a lucrative business and finfish farmers shifted to growing the species. With the industry's progress came problems in sustainability.

Problems in disease and water quality were the main concern of shrimp farmers. Several methods to control these problems were tried by shrimp producing countries in Southeast Asia. During the outbreak of diseases in the early 90 s researchers and farmers tried using intensive liming, antibiotics, and probiotics or bioremediation. The latter was found effective for sustainability (Walker \& Clymo, 1996).

The use of probiotics as bioremediation or biological control is now accepted in the field of aquaculture. Bioremediation is the practice of using supplemental bacteria for wastewater treatment. It is used to achieve and maintain high quality water within the system and improve the quality of discharge water.

\section{USE OF PROBIOTICS}

Probiotics are beneficial bacteria capable of repressing the growth of pathogenic organisms (Moriarty 1998) either through the production of inhibitory substances or by competition (Nogami and Maeda 1992). Their mechanisms of action range from the production of antibacterial substances like organic acids, which lower the $\mathrm{pH}$, to the production of hydrogen peroxide, which can be toxic to pathogens (Mohammed 1995) and metabolites, which can neutralize the toxins released by pathogens (Stavric and D'aoust 1993). Probiotics also play a major role in the production of enzymes that increases the utilization of feeds (Stavric and D'aoust 1993) and improves digestion by colonizing the gut of the cultured organism (GESAMP 1997). They also produce substances that aid in the detoxification of injurious metabolites (Stavric and D'aoust 1993).

Probiotics are composed of selected microbial strains that are naturally occurring in nature. Most brands available in the market are composed of Bacillus species. Probiotics have been used in health foods like milk and yogurt, in industrial wastewater treatment, and recently, in aquaculture. 


\section{Philippines}

Intensive shrimp farming in the Philippines started in the late 70's following Taiwan's success in shrimp farming. However, production was not sustained and began to decline in the mid $90 \mathrm{~s}$. Increased organic matter dumped in the waterways during water management activities resulted in poor water quality. In effect disease outbreak followed, the most serious of which was caused by the luminous Vibrios. Shrimp farmers and aquaculture researchers tried different techniques like the use of liming and antibiotics to improve shrimp survival and sustain production. However, these techniques were not effective. Luminous bacteria continued to proliferate because Vibrios are natural fauna of seawater. In some intensive farms in the provinces of Cebu and Negros Occidental, farm owners had already unknowingly used probiotics in their farms since suppliers classified these products as water quality enhancers.

In 1997, the United Nations Development Programme (UNDP) funded a study to improve and sustain shrimp production. A team was tasked to study the existing shrimp culture techniques and modify these techniques to sustain production without degrading the environment. Results found the use of probiotics as bioremediation sustainable. Further studies were conducted in probiotics to determine why previous use of this technique failed. Different probiotics brands available in the market were studied and it was found that most are freshwater strains, which could be the reason for the failure because farmers used these strains in brackishwater ponds.

Seawater strains were pilot tested in different farms in the Visayas (Cebu and Negros Occidental) and positive results were obtained. Activation technique before application was also developed to maximize the efficiency of the product. Probiotics was used during pond preparation to hasten decomposition of organic matter, particularly during the rainy months when the pond bottom cannot be thoroughly dried. Regular application of probiotics was also done during the culture period to ensure good water quality. Applying probiotics 2-3 times/week was found to effectively maintain good water quality (Corre, et al., 1999). Regular monitoring of parameters was also done to determine the effects of probiotic application on the pond bottom soil.

In ponds with high level of luminous bacteria, feed rations were soaked in activated probiotics prior to feeding. In this manner the shrimps were able to ingest good bacteria in their gut which aided in feed assimilation and cleaned the digestive tract of bad bacteria and toxins. When this method was employed, shrimps that had high level of luminous bacteria in their hepatopancreas recovered quickly and feeding activity was not affected. Result of the study conducted is shown in Table 1.

Table 1. Production parameters in SSAMDC ponds in Dumanjug, Cebu, Philippines

\begin{tabular}{lcc} 
& Control & With probiotics \\
\hline Stocking rate & $45 / \mathrm{m}^{2}$ & $45 / \mathrm{m}^{2}$ \\
FCR & 3.0 & 1.6 \\
Recovery (\%) & $16-72$ & $90-93$ \\
ABW (g) & $26-28$ & $28-33$ \\
Total feeds (tons) & 2.1 & 6.8 \\
Days of Culture (DOC) & 132 & 124 \\
Production (tons) & 0.7 & 4.2 \\
Selling Price (PHP/kg) & 235.00 & 350.00 \\
Total Income (PHP) & $157,500.00$ & $1,487,500.00$ \\
Total Expenditures (PHP) & $291,000.00$ & $716,000.00$ \\
Profit (PHP) & $(133,500.00)$ & $771,500.00$ \\
\hline *Pond size 0.45 ha & $* 1 \mathrm{PHP}=0.02 \mathrm{US} \$$
\end{tabular}

\section{Thailand}

Thailand is the number one shrimp exporting country in the world. In the year 2000, production reached $200,000 \mathrm{MT}$. But like its neighboring Asian countries, Thailand experienced a setback in 1995-1996 because of disease outbreak. Thailand, however, recovered swiftly because of strong government support and farmers' ingenuity.

The use of probiotics has been practiced in Thailand since the mid 90's. Different brands of probiotics are commercially available in the country. In shrimp farms, probiotics are used to improve water quality by reducing waste accumulation. Aside from the regular application (every 3-5 days) in ponds, some shrimp farmers incorporate probiotics in the feeds given to shrimps. This was done to aid in digestion and assimilation of feeds, thus improving the FCR. In a study on shrimp feed preparation inoculated with Bacillus S11 bacterium, Rengpipat et al. (1998), concluded that the use of probiotics reduced shrimp mortality during the culture period.

\section{Indonesia}

In Indonesia, intensive shrimp farming prospered in the $80 \mathrm{~s}$ with the application of new culture techniques developed by neighboring Asian countries. There are about 300,000 ha of ponds in cultivation and about 110,000 ha are used for shrimp farming. (Winarno, 
1995). Despite this vast area, Indonesia ranked only second to Thailand in terms of production.

In 1994, the shrimp industry had its downfall because of disease outbreaks. Scientists from Thailand investigated the cause and histological analysis revealed the presence of gill fouling organisms (Zoothamnium) and viral infection, which may have been caused by the contamination of the water source. Because of this, farmers started employing a biofiltration that used bivalves grown in filtering ponds; bivalves are capable of reducing algal biomass and suspended organic particles (Corre et al 1997). Wastewater from rearing ponds passed through the filtering pond first before being drained.

A shrimp farm in Negara, Bali used probiotics. This was applied during pond preparation to clean the bottom of intensely used shrimp ponds. The probiotics were placed in muslin tea bags and suspended halfway of the water depth. After a period of immersion, the bags are emptied into the pond. Using this method, the water inside the ponds became green, indicating bloom of good quality plankton. A specified dose of probiotics was applied every 3-4 days to maintain the good quality plankton and reduce organic matter accumulation.

Normal schedule of shrimp sampling showed improved quality compared with previous methods employed. The shrimps were observed to have good growth rate and a greenish appearance, indicating good health. A low level of ammonia was also monitored denoting good water quality.

D.J.W. Moriarty (1998) tested probiotics in shrimp farm for its vibriostatic activity. A brand of probiotics was applied every 2-3 days and its effect on Vibrio harveyii (luminous bacteria) was monitored. Moriarty observed that probiotics application noticeably increased the number of Gram-positive bacteria and decreased the number of luminescent Vibrio. Moreover, addition of organic matter in the pond increased the number of bacteria. With probiotics application, the percentage of Grampositive bacteria was higher, which is beneficial for the shrimps. No accumulation of bacteria was observed in the water and sediment during the culture period. However, the population of Gram-positive bacteria decreased a few days after no probiotics was applied. Regular addition therefore is necessary to maintain the population.

Haryanti (1998) also studied the vibriostatic effect of a bacterial strain in larval rearing of Penaeus monodon. Results showed that growth and survival of larvae were higher in tanks inoculated with bacteria (probiotics). Growth population of total bacteria was significantly higher in tanks without probiotics. Thus, probiotics had the ability to suppress Vibrio bacterial density. The same result was also obtained in the study of Moriarty (1998).

\section{Malaysia}

Aquaculture in Malaysia started in the late $19^{\text {th }}$ century and early $20^{\text {th }}$ century. Chinese immigrants started the first brackishwater shrimp culture in the state of Johor by introducing the culture of penaeid prawns in trapping ponds in the mangrove. Intensive shrimp culture started only in 1984 and rapidly expanded until 1995. Production of the giant tiger shrimp increased from 60 tons (1984) to 7,407 tons in 1995 (Choo and Raihan 2000). However, production decreased in the late 90 s because of disease outbreak. Several methods were used to improve shrimp survival, but results varied depending on the place and the capability of the workers. The use of antibiotics was found beneficial in some runs however, production was not sustained during the succeeding crops. It was also observed that the dosages given are continually increasing.

The use of probiotics was tested. Probiotics are used in shrimp farms to improve water quality and shrimp recovery. Trial runs were conducted in shrimp farms located at various parts of the country to determine the action of probiotics and to test its effectiveness in improving water quality to increase production. Results of the runs are presented in Table 2.

Table 2. Production parameters in shrimps ponds in Kuala Langat (Banting), Malaysia.

\begin{tabular}{|c|c|c|}
\hline & Control & With probiotics \\
\hline Stocking rate & $33 / \mathrm{m}^{2}$ & $34 / \mathrm{m}^{2}$ \\
\hline FCR & 2.4 & 1.8 \\
\hline Recovery (\%) & $40-60$ & $85-88$ \\
\hline$A B W(g)$ & $22-24$ & $28-32$ \\
\hline Total feeds (tons) & 5.20 & 9.36 \\
\hline Production (tons) & 2.05 & 5.20 \\
\hline Sales at harvest @\$17.00/kg & $34,833.00$ & $88,400.00$ \\
\hline Lime, etc. & $8,000.00$ & $8,000.00$ \\
\hline Cost of fry @1.7 cents/fry & $3,366.00$ & $3,468.00$ \\
\hline Cost of feeds@2.90/kg & $15,080.00$ & $27,144.00$ \\
\hline Sub-total & $26,446.00$ & \\
\hline Cost of probiotics & - & $2,687.50$ \\
\hline Gross Profit & $8,387,00$ & $47,100.50$ \\
\hline
\end{tabular}

*Pond size 1.5 acres 


\section{REFERENCES}

1. Choo, PS, Raihan, SA. Malaysia: Mangrove-friendly aquaculture. In: Primavera, JH, Garcia, LMB, Castaños, MT, Surtida, MB (eds). Mangrove-Friendly Aquaculture. Proceedings of the Workshop on Mangrove-Friendly Aquaculture (January 11-15, 1999) SEAFDEC-AQD, Philippines. 2000, pp.81-94.

2. Corre, KG, Corre, VL, Gallardo, W. The Growth, Survival and Production of Shrimp (Penaeus monodon) Cultured with green Mussel (Perna viridis) in SemiIntensive Ponds. UPV J. Nat. Sci. 1997; 2:1-8.

3. Corre, VL Jr., Janeo, RL, Caipang, CMA, Calpe, AT. Sustainable shrimp culture techniques: use of probiotics and reservoir with "green water". Philippine Council for Aquatic and Marine Research and Development, Los Baños, Laguna and the University of the Philippines in the Visayas, Miag-ao, Iloilo. 1999.32pp.

4. GESAMP. Towards safe and effective use of chemicals in coastal aquaculture. Rep. Stud. GESAMP 65. 1997, 40pp.

5. Haryanti, K, Sugama, Lante, S, Tsumura, S. Use of BY-9 as probiotic in $P$. monodon larval rearing. Agency for Agricultural Research and Development (AARD) of Indonesia. 1998. 17pp.

6. Mohammed KS. An emerging concept in aquaculture nutrition and diseases control. Seafood Export J. 1995; 26(7):5-9

7. Moriarty DJW. Control of luminous Vibrio species in penaeid aquaculture ponds. Aquaculture 1998; 164:351358

8. Nogami, K, Maeda, M. Bacteria as biocontrol agents for rearing larvae of the crab Portunus trituberculatus. Can.J. Fish. Aquat. Sci. 1992; 49(11):2373-2379.

9. Rengpipat, S, Phianphak, W, Piyatiratitivorakul, S, Menasveta, P. Effects of a probiotic bacterium on black tiger shrimp Penaeus monodon survival and growth. Aquaculture 1998; 167: 301-313

10. Stavric, S, D'Aoust, JY. Undefined and defined bacterial preparations for the competitive exclusion of Salmonella in poultry - a review. Journal of Food Protection 1993; 56(2):173-189.

11. Walker, T, Clymo, P. Fighting prawn diseases with bacterial inoculation of ponds. Austasia Aquaculture 1996; 10(2): 27-45.

12. Winarno, B. Shrimp Aquaculture in Indonesia. In: Browdy, CL, Hopkins, JS (eds). Swimming Through Troubled Waters. Proceedings of the Special Session on Shrimp Farming. World Aquaculture Society. 1995, pp. 24-28 